\title{
Teaching NeuroImages: When MRI is a clue in episodic ataxia
}

Sumeet R. Dhawan, MD, DM, Arushi Gahlot Saini, MD, DM, Sameer Vyas, MD, DM, and Savita Verma Attri, PhD, MAMS, FIMSA

Neurology ${ }^{\circledR}$ 2019;93:e2074-e2075. doi:10.1212/WNL.0000000000008563

Figure MRI in maple syrup urine disease
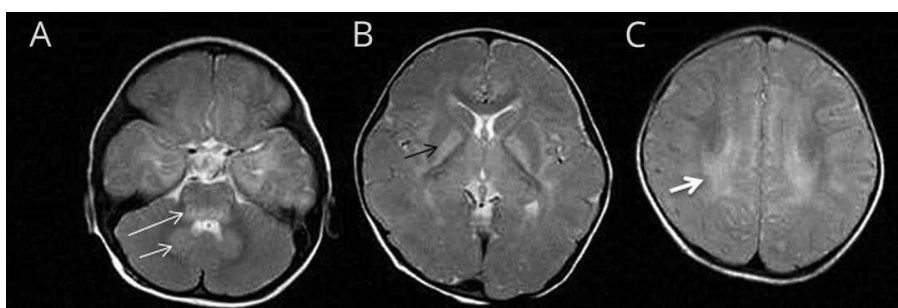

D

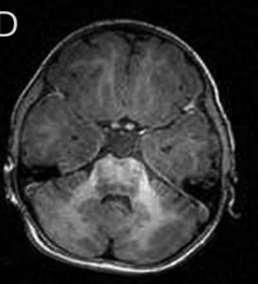

$\mathrm{E}$

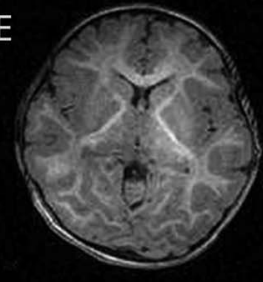

F
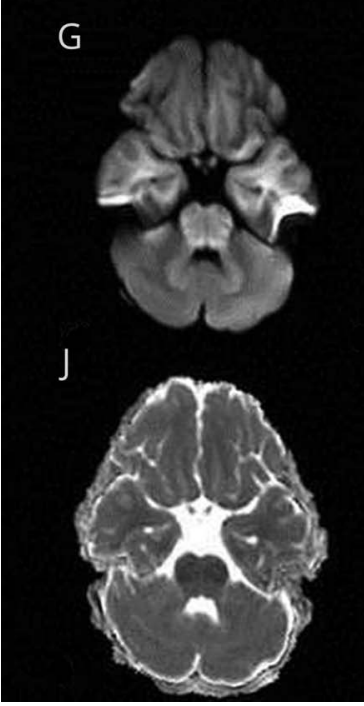

H I

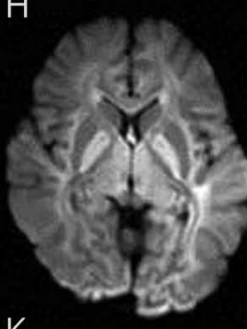

K
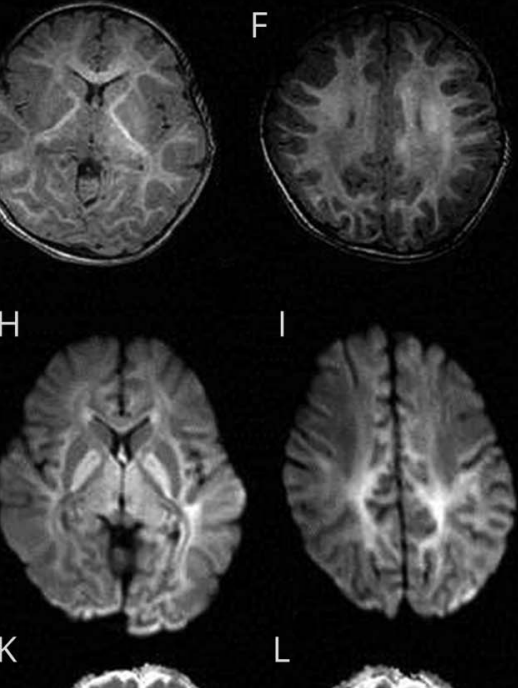

I

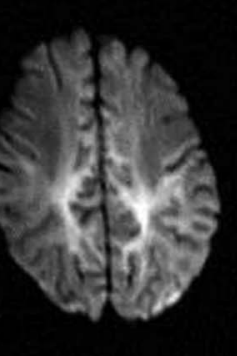

L
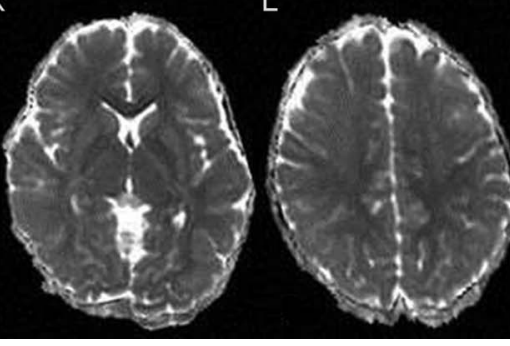

MRI shows hyperintense signal in (A) cerebellar deep white matter including nuclei (short white arrow) and dorsal pons (long white arrow), (B) globus pallidi (black arrow) and thalami, and (C) bilateral cerebral white matter (white arrow) in axial T2 scan. These changes are hypointense on T1 scan (D-F). Diffusion-weighted images $(G-I, b=1,000)$ and apparent diffusion coefficient (J-L) show acute diffusion restriction.

A 3-year-old girl presented with episodic ataxia for the past month. It lasted for 1-2 days continuously after a febrile illness. MRI was suggestive of a neurometabolic disorder (figure, A-L). Plasma valine and leucine and urinary branched-chain aminoacids were

\section{Correspondence}

Dr. Saini

doc.arushi@gmail.com
MORE ONLINE

\section{$\rightarrow$ Teaching slides}

links.lww.com/WNL/B3

From the Pediatric Neurology Unit, Department of Pediatrics (S.R.D., A.G.S., S.V.A.), and Department of Radiodiagnosis (S.V.), Post Graduate Institute of Medical Education and Research, Chandigarh, India.

Go to Neurology.org/N for full disclosures. Funding information and disclosures deemed relevant by the authors, if any, are provided at the end of the article. 
elevated. Clinical exome revealed a homozygous, missense, pathogenic variation in $B C K D H B$ gene (exon 5, chr6: 80878686A>C; p.His191Pro).

Patients with intermittent maple syrup urine disease (MSUD) may develop episodic decompensation during periods of stress secondary to acute leucinuria and abnormal neurotransmitter activity. ${ }^{1}$ Bilateral, symmetrical diffusion restriction in myelinated areas of the brain is seen in aminoacidopathies, including MSUD, nonketotic hyperglycinemia, and Canavan disease. ${ }^{2}$

\section{Study funding}

No targeted funding reported.

\section{Disclosure}

The authors report no disclosures relevant to the manuscript. Go to Neurology.org/N for full disclosures.

Appendix Authors

\begin{tabular}{|c|c|c|c|}
\hline Names & Location & Role & $\begin{array}{l}\text { Role and } \\
\text { contribution }\end{array}$ \\
\hline $\begin{array}{l}\text { Sumeet R. } \\
\text { Dhawan, } \\
\text { MD, DM }\end{array}$ & $\begin{array}{l}\text { Postgraduate } \\
\text { Institute of Medical } \\
\text { Education and } \\
\text { Research, } \\
\text { Chandigarh, India }\end{array}$ & Author & $\begin{array}{l}\text { Original drafting } \\
\text { and revising the } \\
\text { manuscript for } \\
\text { intellectual } \\
\text { content }\end{array}$ \\
\hline $\begin{array}{l}\text { Arushi } \\
\text { Gahlot } \\
\text { Saini, MD, } \\
\text { DM }\end{array}$ & $\begin{array}{l}\text { Postgraduate } \\
\text { Institute of Medical } \\
\text { Education and } \\
\text { Research, } \\
\text { Chandigarh, India }\end{array}$ & $\begin{array}{l}\text { Corresponding } \\
\text { author }\end{array}$ & $\begin{array}{l}\text { Clinician-in- } \\
\text { charge, } \\
\text { conceptualization } \\
\text { of the study, } \\
\text { critical review of } \\
\text { the manuscript } \\
\text { for intellectual } \\
\text { content }\end{array}$ \\
\hline
\end{tabular}

Appendix (continued)

\begin{tabular}{|c|c|c|c|}
\hline Names & Location & Role & $\begin{array}{l}\text { Role and } \\
\text { contribution }\end{array}$ \\
\hline $\begin{array}{l}\text { Sameer } \\
\text { Vyas, MD, } \\
\text { DM }\end{array}$ & $\begin{array}{l}\text { Postgraduate } \\
\text { Institute of Medical } \\
\text { Education and } \\
\text { Research, } \\
\text { Chandigarh, India }\end{array}$ & Author & $\begin{array}{l}\text { Analysis and } \\
\text { interpretation of } \\
\text { radiologic data, } \\
\text { critical review of } \\
\text { the manuscript }\end{array}$ \\
\hline $\begin{array}{l}\text { Savita } \\
\text { Verma } \\
\text { Attri, } \\
\text { PhD, } \\
\text { MAMS, } \\
\text { FIMSA }\end{array}$ & $\begin{array}{l}\text { Postgraduate } \\
\text { Institute of Medical } \\
\text { Education and } \\
\text { Research, } \\
\text { Chandigarh, India }\end{array}$ & Author & $\begin{array}{l}\text { Biochemical } \\
\text { analysis, revising } \\
\text { the manuscript } \\
\text { for intellectual } \\
\text { content }\end{array}$ \\
\hline
\end{tabular}

\section{References}

1. Cheng A, Han L, Feng Y, et al. MRI and clinical features of maple syrup urine disease: preliminary results in 10 cases. Diagn Interv Radiol 2017;23: $398-402$.

2. Blackburn PR, Gass JM, Vairo FPE, et al. Maple syrup urine disease: mechanisms and management. Appl Clin Genet 2017;10:57-66. 


\section{Neurology}

\section{Teaching NeuroImages: When MRI is a clue in episodic ataxia}

Sumeet R. Dhawan, Arushi Gahlot Saini, Sameer Vyas, et al.

Neurology 2019;93;e2074-e2075

DOI 10.1212/WNL.0000000000008563

This information is current as of November 25, 2019

Updated Information \& Services

References

Subspecialty Collections

Permissions \& Licensing

Reprints including high resolution figures, can be found at: http://n.neurology.org/content/93/22/e2074.full

This article cites 2 articles, 0 of which you can access for free at: http://n.neurology.org/content/93/22/e2074.full\#ref-list-1

This article, along with others on similar topics, appears in the following collection(s):

Metabolic disease (inherited)

http://n.neurology.org/cgi/collection/metabolic_disease_inherited

Information about reproducing this article in parts (figures,tables) or in its entirety can be found online at:

http://www.neurology.org/about/about_the_journal\#permissions

Information about ordering reprints can be found online:

http://n.neurology.org/subscribers/advertise

Neurology ${ }^{\circledR}$ is the official journal of the American Academy of Neurology. Published continuously since 1951, it is now a weekly with 48 issues per year. Copyright @ 2019 American Academy of Neurology. All rights reserved. Print ISSN: 0028-3878. Online ISSN: 1526-632X.

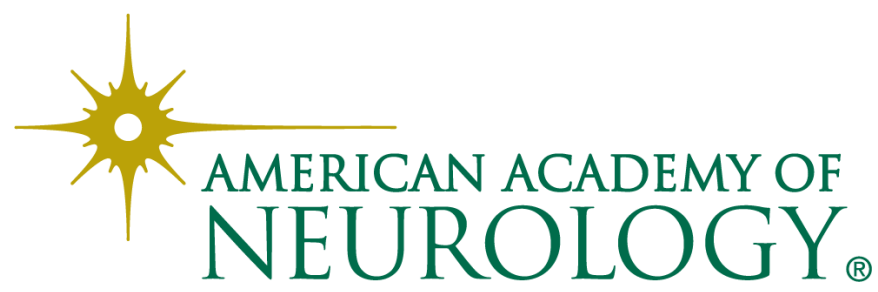

